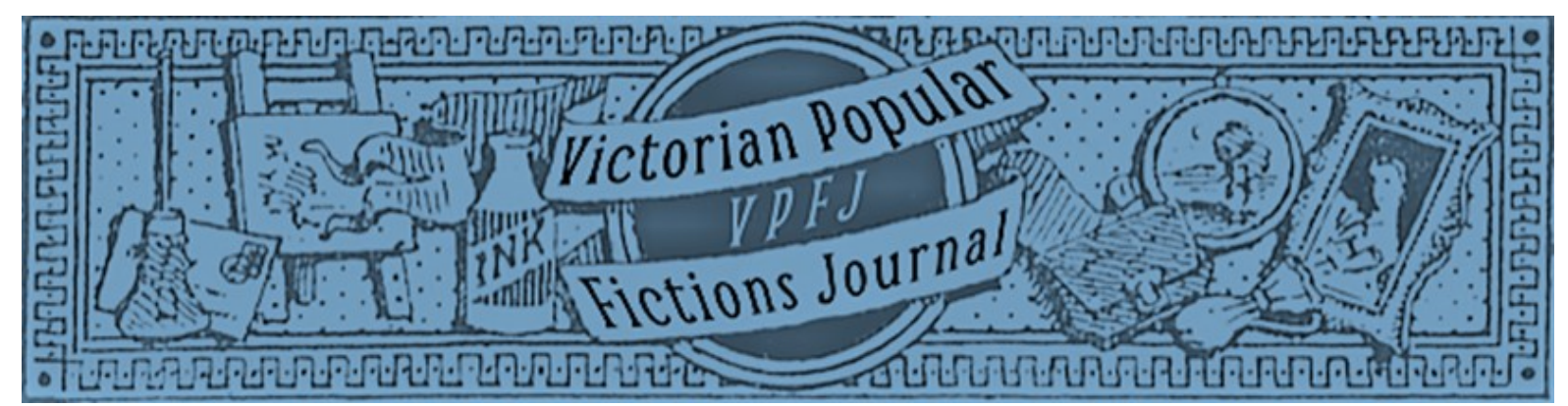

\title{
Stage Piracy in Victorian Britain: Bleak House Adaptations
}

\author{
Julianne Smith
}

\begin{abstract}
Pirating novels for the stage was a staple of the Victorian theatre. There were many theatrical piracies of Bleak House in the second half of the period, but they all share a common feature: pirates had to decide how to reshape the narrative for audience consumption since the whole of this sprawling novel was impossible to stage. Thus fidelity to the original text was out of the question. This essay examines two Bleak House adaptations, an early and largely forgotten version and a later version that gained a global reputation. It considers the range of challenges pirates faced when adapting Bleak House as well as how the narrative is adapted to audience expectations across time and genre in the late Victorian period so that, out of the novel's multivocality, Jo emerges as the centre of the story.
\end{abstract}

\section{Keywords}

Charles Dickens; Bleak House; Victorian Theatre; Adaptation Theory; Austin Lee; J. P. Burnett; Jennie Lee; Jo

Date of Acceptance: 8 December 2021

Date of Publication: 17 December 2021

Double Blind Peer Reviewed

\section{Recommended Citation:}

Smith, Julianne. 2021. "Stage Piracy in Victorian Britain: Bleak House Adaptations." Victorian Popular Fictions, 3.2: 98-115. ISSN: 2632-4253 (online) DOI: https://doi.org/10.46911/ABEP5540

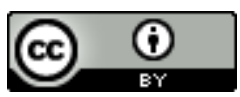

This work is licensed under a Creative Commons Attribution 4.0 International License. 


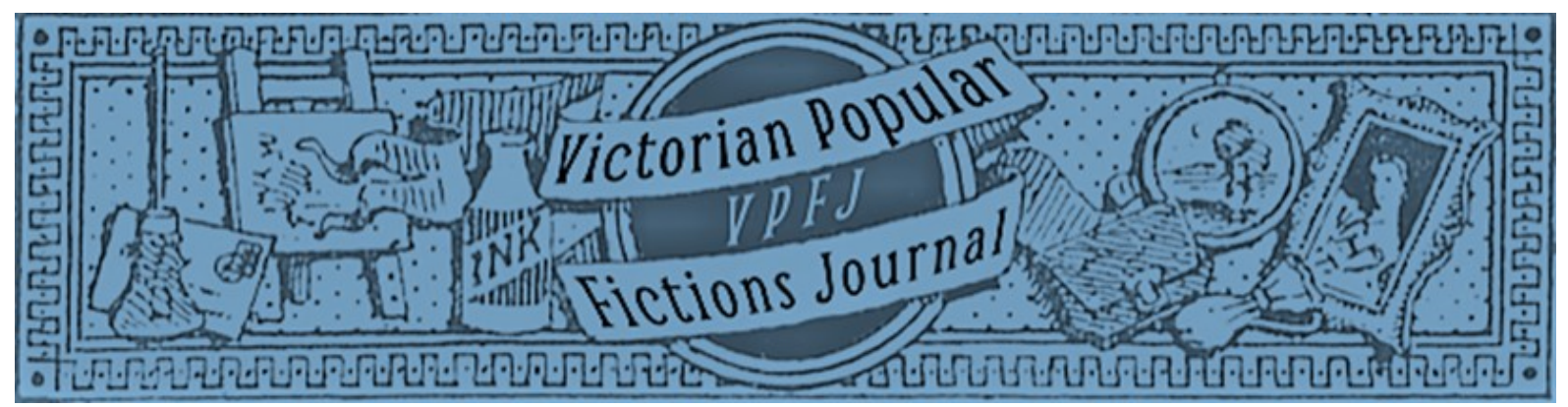

\title{
Stage Piracy in Victorian Britain: Bleak House Adaptations
}

\author{
Julianne Smith
}

\section{Introduction}

The two Bleak House piracies examined here are an obscure version staged in 1853 and a blockbuster version staged in 1876. As was typical for theatrical pirating of Dickens's novels, the 1853 adaptation was on stage before the novel's serial publication ended - and likely before Dickens had finished writing it. The narrative's unfinished state was a gamble for pirates, who had to reshape the story and improvise an ending, risking or maybe even expecting transience by later comparison with the completed original. Adaptors also gambled on audience desire for further imaginative connection with Dickens's characters. As contemporaneous readers, Bleak House audiences may have felt disappointment or delight at the adaptor's selections of scenes and characters but certainly must have anticipated some pleasurable engagement with the unfolding action of the book, though they could not have expected complete fidelity since it was only partially complete. Though the 1853 adaptation opened well and attracted audiences for a few weeks, it subsequently disappeared entirely. The wildly successful 1876 version, on the other hand, had decades of access to the completed text, but it too improvised on and reshaped the narrative, risking the censure of audiences long familiar with the story. There are a few recorded objections to the liberties taken by the 1876 play, but audiences voted at the box office, buying tickets in droves over several decades of production. This article positions both pirated plays as creative iterations of the Bleak House narrative and of each other. As pirated and therefore unauthorised entities, they bid for authority in illicit ways that provide insights into how Victorians read, remembered, interpreted or reshaped the text. I argue that, in its multivocality, Dickens's Bleak House accommodates the partial and new readings these piracies represent. Therefore, the pre-emptiveness of the forgotten 1853 piracy deserves examination for the very reason that it is partial and voices the unfinished-ness of Bleak House in that moment. By contrast, the more successful and profitable 1876 piracy appealed to the emotional aesthetic of late-Victorian audiences, whose taste for nostalgia and melodrama onstage it apparently satisfied in droves. By selecting one voice out of the cacophony of voices 
Bleak House makes available and asserting its primacy, the 1876 play attained a narrative authority that, for a time, superseded that of Dickens's own. Both piracies, in fact, subvert Dickens's authority in differing but related ways, effectively placing Jo at the narrative's centre by foregrounding his voice out of Bleak House's multiplicity of competing voices.

Theatrical pirating of Dickens was a regular occurrence beginning with his earliest publications since copyright laws did not fully prohibit piracy of novels for the stage until 1911. ${ }^{1}$ Dickens novels, then, were never fully protected until decades after his death in 1870. Scholars have outlined the ways Dickens was involved in the complicated but gradual assertion of authors' rights over their texts in his own lifetime, ${ }^{2}$ but there are ambiguities about just how much Dickens himself objected to the practice of stage piracy when it came to his own novels. Monica Cohen argues that Dickens's conduct suggests he was divided on the issue: although he was "a legendary denouncer of dramatic pirates," his own narrative choices often reflected the idea that "piracy is both artistic scourge and a reflection of how creativity works" (2018: 125) - that is, especially in performances, "creativity ... is collective" (124) and relies on the combined efforts of the original author, the adaptor, the actor and other theatrical elements and personnel. In the earlier part of his career, Dickens approved and actually collaborated with some Victorian adaptors while he bemoaned the rampant and unauthorised adaptations of others. For example, he gave explicit permission and endorsement to Edward Stirling to write a version of Martin Chuzzlewit in 1844, even attending rehearsals and working with the performers. This lucrative and popular production, mounted at The Lyceum, ran for more than 8 months in its initial production (Bratton 2017: 27). Dickens's approval lent his authority to certain adaptations, and this cachet often translated into stage success and audience approbation. In contrast, the short-lived 1853 Bleak House production examined below did not have Dickens's consent or approval, and the later 1876 production cannot have had Dickens's permission since it was produced after his death. Unlike several other Dickens novels, Bleak House does not seem to have had a Dickens-approved adaptation at any point. As well, Bleak House's trajectory as a pirated production suggests that pirates did not see the narrative as particularly ripe for pillaging at first - stymied, perhaps, by the novel's crowded and complex plotlines. Though there were a few different Bleak House adaptations in the early 1850s that did not catch on with the public, most Bleak House adaptations occurred in the 1870 s in the avalanche of stage piracies many of Dickens's works underwent just after his death (Bolton 1987: 349).

Adapting Dickens has been regular fare for stage and screen both in the nineteenth and twentieth centuries, and today's readers and scholars will find that pirated Dickens adaptations are being recovered in print, signaling a renewed interest in their place in literary history and critical examination. ${ }^{3}$ In the Victorian period, plays were often not published for a number

\footnotetext{
${ }^{1}$ Laws were passed in 1833 and 1842 asserting that published texts were the author's intellectual property, but they did not require an author's permission to adapt or perform a published text. For more on the nuances of The Dramatic Copyright Act of 1833 and Talfourd's Literary Copyright Act of 1842, see Alexander (2010a), Mattacks (2016), Miller (2018), and Seville (2007).

${ }^{2}$ For more on Dickens and his fight for copyright, see Patten (2018) and Fielding (1956).

${ }^{3}$ See Dickensian Dramas, two recently published volumes of Dickens adaptations for the stage edited by Bratton (2017) and Davis (2017).
} 
of reasons, ${ }^{4}$ though each manuscript had to be registered with the Lord Chamberlain's Office where they are still extant. An examination of these manuscripts shows a clear pattern in adapting Dickens: an initial "flurry of plays" followed years or even decades later by another round of adaptations (Fulkerson 1974: 83). In the nineteenth century, Bleak House was adapted for the stage in at least twenty-nine versions with, according to Philip Bolton, more than a hundred stagings, including burlesques and parodies (1987: 349). In the succeeding centuries, the $\mathrm{BBC}$ has regularly produced Dickens adaptations, not the least of which was the awardwinning mini-series Bleak House in 2005.

The pirated adaptations examined here shaped readings of Bleak House that highlight Victorian tensions between printed vs. performed texts. They also make legible an answer to a question about Dickens's narrative itself - that is, what is this story about? Stage pirates appropriated and re-appropriated stray narrative threads and sold Bleak House to the public in a changed form and sometimes with new names. Some of them successfully subverted Dickens's authority for a time, taking advantage of his success at the same time they paid tribute to it.

\section{Dickens and Victorian Adaptation}

The approach playwrights took to adapting Dickens varied. Some merely abstracted parts of his text while others, who interpolated their own scenes and characters, went well beyond mere copying. Attempts to match the spirit of Dickens's literary imagination set up the adaptor as a kind of authorial rival since a playwright might successfully improvise on the original, calling into question the actual inimitability of The Inimitable himself. In addition, Bleak House, in its multivocality and with its sprawling subplots and nearly a hundred characters, is supremely open to a variety of adaptations since it is more of an ensemble novel than many of Dickens's others, such as Oliver Twist and David Copperfield whose focus is prescribed by titular characters

Adaptors struggled to rein-in and confine Bleak House to manageable stage proportions, adding and deleting characters in what may at times seem whimsical at best and jolting at worst. The difficulties of adapting Dickens for the Victorian stage fell into three categories. First, adaptors had to contend with Dickens's vast readership and therefore relied too heavily on the audience's previous knowledge of the plot. Dickens's readership reached new proportions over the course of the nineteenth century. Beginning with The Pickwick Papers in the 1830s, Dickens's works commanded large initial print runs typically between 20,00040,000 copies. Before Dickens's death, cheap reprints of his works became available, and in the decade or so after his death, one estimate puts the reprint figure in England at over four million copies sold (Altick 1998: 384). By the end of the century, Dickens's works were included in such series as the Penny Library of Famous Books, which, Richard Altick points out, still does not saturate the market as more and more avid readers snap up the opportunity to own copies at affordable prices (315). Given this level of readership, Dickens's novels in print form might naturally be assumed to shape an audience's expectations about stage versions throughout the nineteenth century. However, playwrights' assumptions that audiences

\footnotetext{
${ }^{4}$ Derek Miller explains that, in the second half of the Victorian period, "dramatizers had every right to adapt the novel for the stage but had no right to print their adaptations. The printed form of a dramatized novel infringed the author's copyright insofar as it copied the novel" (2018: 145). As well, Victorian playwrights were often reluctant to publish their plays because printed texts could be easily commandeered and, with some changes to the texts, could be reprinted in collections such as John Dick's or Thomas Lacy's Acting Editions (Mattacks 2016: 135-41).
} 
already knew the plot beforehand often made for sloppy organisation. Jim Davis speculates that a Victorian audience's familiarity with Dickens made the more incoherent adaptations comprehensible since they could fill in characters and elements that were not portrayed, went missing or were only briefly alluded to (2017: 17). Adaptors might therefore introduce characters who then disappeared entirely and often inexplicably from their plays. The 1853 Bleak House adaptation discussed below may have counted on this familiarity to fill in some of its erasures. And, since adaptations are an imaginative shorthand for the narrative, they serve as an index of the dialogic relationship between Bleak House, untimely adaptation, and audiences who are familiar with the text.

A second challenge in adapting Dickens, as noted above, was that his novels are too voluminous and complex to aim at complete fidelity or comprehensiveness. Many early adaptations lifted bits and scraps of Dickens's novels wholesale from the text and used his dialogue to piece together scenes that moved from one tableaux vivant, drawn directly from Hablot K. Browne's and Fred Barnard's well-known illustrations, to the next. The effect of this was a somewhat unifying familiarity since it reminded audiences of their reading experience, but it did not necessarily create satisfying theatre given the number of characters and plots to be accommodated in many of the novels. A review from The Times in 1881 (after Dickens's death) notes that, since the "original illustrations are no longer in every one's hands, and a new generation has arisen which knows Dickens from editions without the plates, this method has naturally been discarded" ("The Theatres" 1881: 10C). Lacking this unifying visual principle, adaptations moved further away from the mooring of Dickens's original texts. Playwrights had to select other elements to hold these plays together, as in the case of Bleak House, where many adaptations identified a specific character, who anchored the play, and the rest of the characters existed in relationship to him or her. Since Bleak House does not identify a central character in its title, playwrights' choices might be unexpectedly influential when they set out to make this sprawling novel into a stage presentation.

A third challenge in adapting Dickens was a sense that his talent for supreme caricature could not be equalled or adequately re-created by his dramatic adaptors - and perhaps by the actors themselves. George Bernard Shaw skewered the actors in a Bleak House adaptation he saw on stage in 1896:

One facility offered to the stage by Dickens is a description of the persons of the drama so vivid and precise that no actor with the faintest sense of character could mistake the sort of figure he has to present, even without the drawings of Browne and Barnard to help him out. Yet each attempt only proves that most of our actors either have no character sense or have never read Dickens.

(1932: 134-5)

Shaw asserts that Dickens is ironically too dramatic for the stage - too heavy-handed. Those who attempt a portrayal must choose between fidelity to Dickens, which results in falseness or "stage facetiousness" (1932: 136), and fidelity to artistic integrity, which, in Shaw's view, meant the move toward Ibsenesque realism. Dickens, with his keen love of detailed caricature, left no space for artistic interpretation in the view of many critics, nor was he aiming at the kind of realism late-Victorian playwrights adopted. Shaw's point is that Dickens offers all-or-nothing characters, who must be utterly embodied for fidelity or completely changed to match emerging tastes. In the case of Bleak House, Dickens delineates so many eccentric characters - Snagsby, Krook, Miss Flite, Bucket, Chadband, Guppy, Skimpole, Smallweed and, of course, Jo to name a few - that they threaten to overcome the forward motion of the plot with too many asides and distractions. Adaptors, then, were spoiled for choice and had to select judiciously for stage success. 
Given this set of adaptation problems, Bleak House piracies are most usefully examined as discrete texts that are in conversation with one another rather than being evaluated by their individual fidelity to the original. Adaptation theory suggests that adapted texts, especially across genres, are necessarily different from the original and can never achieve a state of complete fidelity. At the same time, adapted texts resonate with the original in different ways so that selecting vocabulary to describe this more complex relationship is necessary. Instead of measuring the adaptation against the original for fidelity, adapted texts might be better described as "transcoded" or reimagined (Hutcheon 2012: 6-8). Other terms are constructive as well: recombined, rewoven, remediated or re-appropriated. These notions provide the basis for this study but express a more philosophical than popular approach to adaptation reception, though popular reception will also be addressed below. This Bleak House analysis considers the way pirates rewove the story as threads of the plot were picked out and made central to new patterns of narrative expression. Victorian stage pirates had one eye on Dickens's text and one on the elements they thought would be popular on stage as they re-appropriated the narrative, with the chief outcome that these piracies were unexpectedly influential in repositioning Bleak House as primarily Jo's story in the Victorian imagination.

\section{Bleak House Onstage 1853: Austin Lee, Bleak House, in Two Acts}

Though Austin Lee was not the very first Bleak House pirate to stage the novel, he only missed that distinction by a matter of hours. George Dibdin Pitt's version appeared at the Royal Pavilion Theatre on 4 June 1853; two days later on 6 June, Lee's version, Bleak House, in Two Acts, trailed Pitt at the City of London Theatre. This theatre, in a working-class East-End neighbourhood, had a long history of Dickens piracy since the very first production staged there was Edward Stirling's Pickwick Club in 1837. One historian categorises the City of London as a minor venue and notes that, "owing to a remote situation, and other causes, it scarcely ever achieved Fame, and never Fashion ..." (Williams 1882: 47). By 1868, it had become a Penny Gaff, the cheapest form of popular theatre aimed at the working classes. Therefore, patrons of this theatre were not the fashionable élite but neither were they disconnected from mainstream Victorian culture since, as Jim Davis and Victor Emeljanow argue, East End theatres "almost certainly includ[ed] a wider social mix than many accounts imply" (2001: 47). For example, the City of London audiences had a large Jewish component, and Davis and Emeljanow quote from a police report issued in 1845 that not only were these audiences "orderly and paying great attention to the performances" but that

the Boxes and the pit were as respectable as one may expect to find at a Theatre, surrounded by the working classes of the Metropolis. Those that were in the Boxes consisted of Tradesmen and their wives and families, all cleanly dressed and very respectful.

(2001: 51)

In sum, Lee's adaptation may not have been written for the elite but also was not tailored to the criminal underclasses whom many, including the police, feared made up this theatrical outpost. In a larger way, the City of London's apparent eagerness to pirate Dickens regularly exemplifies Dickens's appeal across class and social lines. Bratton notes that East End theatres often provided more direct and graphic social critique starting in the 1840s (2017:30), a time of social crisis exemplified by the Chartist movement and working-class uprisings that bid for increased political power and representation. Playwrights for these first East End productions, then, read Bleak House to select voices and plotlines with the greatest audience appeal on several levels. As I have argued elsewhere, Lee's rival at the Pavilion theatre, George Dibdin Pitt, was certainly class conscious in his Bleak House adaptation, selecting voices out of the narrative 
that tested and challenged class stereotypes. Pitt's underclass characters are more complex and culturally aware than even Dickens represents (Smith 2014: 2-20). Lee's version features lessof this sensibility but, in a similar way, still teases out critical class discourses that trouble the Bleak House plot. Therefore, the first pirated Bleak House versions sorted out the narrative in highly experimental ways that tentatively, and perhaps unconsciously in some ways given the unfinished nature of the text, settled on the underclass Jo as the novel's pivot point.

Like many Victorian plays, Lee's version of Bleak House was produced but never published, and the state of his manuscript suggests that this play was hurriedly and carelessly composed. Sentence structure is ignored, and editing or even reading the play for coherence presents some problems. Spelling of character names is inattentive: Hawden is often Howden or Howard, Tulkinghorn consistently lacks a g, Jo is always Joe and Miss Flite is most often but not always Flight. There are two scene fours in act one, and significant words in sentences are sometimes omitted. Scenes are rushed through at a breakneck pace. In addition, Lee forgets to follow up on plot points or fails to consider their relevance. For example, he makes two vague references to Hortense and some mode of French conspiracy against Esther aided by "the agents of Kenge \& Carboys [sic] [who] are lurking in several secret places" to "seize" her (Lee 1853: II. ii). But Hortense herself does not appear as a character, and the Kenge \& Carboys references depend entirely on the audience's familiarity with the novel for explanation. Finally, in a major move away from Dickens's narrative, Bucket is cut out altogether.

Given these issues, Lee's pirated version may have seemed textually compressed and somewhat confusing to audiences, whether or not they were following Bleak House's serial parts as they were being issued. In Lee's narrative economy, Bleak House sets out as Esther's story and is structured by courtship and marriage problems. Esther combines the beleaguered ingénue of melodrama and the gothic heroine adrift from her social and biological identity, and since she narrates about half of the novel itself, she was an obvious focus for adaptors in the novel's unfinished state. ${ }^{5}$ Allan Woodcourt is, of course, the virtuous hero to Esther's virtuous heroine. Richard and Ada are also a focus in Lee's play, though later adaptors found these two mostly expendable. And finally, Lee incorporates the Lady Dedlock and Sir Leicester pairing to bring together wealth, class and birthright issues that both trouble and resolve the question of Esther's parentage and identity. In sum, Lee deploys these couples to structure the stages of domestic courtship and marriage from first love (Esther and Woodcourt) to engagement (Richard and Ada) to matrimony (the Dedlocks). This organisation seems straightforward in many ways, but as the play progresses, Dickens's unfinished narrative and Lee's uncertainties about the plot's ending subvert this course of events.

Act I begins with a summary of the Jarndyce householders (who are already living together), their meeting with Miss Flite, and their subsequent encounter with the drama around Nemo's death at Krook's shop. Lady Dedlock and her household are also introduced in this act. However, Lee makes certain adjustments, most notably to Lady Dedlock, who is much changed in temperament from Dickens's rendering; though she is still famously bored, her outright contempt for Sir Leicester is pronounced. She calls him names ("Deadlong Dedlock") and openly says that he is the cause of the boredom that characterises her so strongly in

\footnotetext{
${ }^{5}$ Interestingly, some later adaptors diminished Esther's role or cut her out of the story altogether. J. B. Johnstone's Jo, A Drama in Four Acts (1876) presents Lady Dedlock as Jo's mother, as does Peter Davey's Poor Jo: A New Version of an Old Play (1912).
} 
the novel. This affront provokes Mrs Rouncewell to a sympathetic speech about "[h]ow gentlemanly he bears all her ill tempers" (I. iv). Lady Dedlock is more theatrical shrew than haughty aristocrat in Lee's play and suggests that East End theatre audiences will find this raucous view of the aristocracy more congenial or amusing than Dickens's restrained and decorous Dedlock household.

Lee's narrative continues to follow Dickens's main structure with Esther, Nemo, Tulkinghorn and the Dedlocks performing essentially the same roles as in the novel but with significant erasures and accommodations. For example, the ghost of Nemo appears to Lady Dedlock and Esther on the Ghost Walk at the end of Act I and reveals their mother/daughter relationship, enhancing the gothic appeal of the play in this departure from Dickens. Jo has been introduced as the crossing-sweeper in the Inkwich scene in Act I, scene five, and is reintroduced in Act II as Smallwood's porter. When Smallwood gives him an undersized tip, he refuses it saying, "I'm poor in pocket, but I scorns to take nothing from the poor in spirit" (II. i). He goes on to lecture Smallweed that the poor

gets their bread in some odd way or another by hard working and making theirselves useful, and that's more than many can say as drives over 'em in their carriages and looks upon ['em] as dogs and dirt under their feet.

Lee increases Jo's presence in the play by casting him in this slightly expanded role and making him the defender of working-class integrity. The effect is to remind the audience of Jo's presence in the largely domestic narrative and situate him as much more articulate and culturally savvy - more privy to working-class injustices and moral integrity - than Dickens's own benighted waif. Besides the Inkwich scene in Act I and the Smallwood scene in Act II, Jo does not figure prominently in the play's main action. Even the novel's memorable cemetery scene with Jo and Lady Dedlock is compressed into these six short exchanges between the two:

Scene $4^{\text {th }}$ Exterior of Churchyard

(Enter Jo followed by Lady Dedlock)

LADY DEDLOCK: I wonder if this lad could inform me - and yet, how shall I make him sensible of what I want? Is there not a burying ground about where they bury the poor paupers?

JO: Oh yes, this here be it. It's chuck full, tho' I don't think you could shove a babby in if so be you wanted to do it. I've seed folks bring little coffins and boxes here to get the gravedigger to pop'em in somewhere's. He gets a shillin by it, but there ain't no room now. I seed that when they put him there.

LADY DEDLOCK: Who do you mean by him?

JO: Why, the only friend as ever I had in this world, and he was werry good to me, he was. I seed him buried. (Wiping his eyes) There he lies, just up in that corner next to the waterspout. He be almost above ground now. I believe that I could scratch him up in less than a quarter of an hour and be sorry for it, for I wanted to be buried alongside of him. He were a gentleman bred and born, for he were werry good to me he was. Why, Master Krook used to call him 'Nimrod,' and Mr Snagsby call'd him nothing but gentleman.

LADY DEDLOCK: Enough! I have gained the intelligence I wanted. Here is something for speaking well of the poor gentleman. Show me the place once again.

JO: That I will.

(Exeunt)

Lee has truncated this scene for the stage, leaving in Jo's sorrow but leaving out Dickens's nuances that inscribe Lady Dedlock's shuddering disdain for Jo and the threat of real and metaphysical contamination as she: 
shrinks into a corner ... of that hideous [cemetery] archway, with its deadly stains contaminating her dress; and putting out her two hands, and passionately telling him to keep away from her, for he is loathsome to her, so remains for some moments. Jo stands staring, and is still staring when she recovers herself.

(Dickens [1853] 1996: 243)

Lee's Lady Dedlock is brusque and unmoved by what Jo shows her, comporting with her transformation into stage shrew with business to transact. Her lines show no emotion about her surroundings or about the death of her beloved Captain Hawdon, though perhaps the actress added these in performance. Jo gets the emotional lines that at least help set up his emergence at the end of the play as the central tragedy. But Jo is not portrayed as ill and does not pass on small pox to Esther. Thus it is a little surprising when he pops up sick and dying in the last scene of the play - except, of course, to Dickens's readers.

The last scene of the play is also set on the Ghost Walk and compresses a lot of action into a little space. With a dozen or more characters in the mix, Lee stages there a life-and-death scuffle in which George shoots and kills Tulkinghorn, who has just expressed evil designs to abduct and marry Esther himself. Esther has become a rich heiress because Jarndyce \& Jarndyce was resolved in Chancery in her favour. Lady Dedlock is revealed to have been legally married to the deceased Hawdon so that her "honour has not moulted a feather" (II. vi.). Thus all is well as the Dedlocks give Esther and Woodcourt their blessing to marry. But that is not the end of the play. There is Jo to deal with.

Why does Jo end this play? Assuming that Lee was reading the serial parts as they were issued up until 6 June 1853, he was not privy to - and indeed does not appear to suspect how Bleak House's denouement will play out. But he is certain about Jo. Chapters 47-49 were issued in May, and these were the final chapters Lee would have had access to. Bolton points out that Chapter 47, the death of Jo, seems to signal playwrights that Bleak House has reached a poignant climax (1983: 82-84). However, the other two chapters contain critical high points as well: Chapter 48 features Tulkinghorn's murder, and in chapter 49, Bucket arrests George Rouncewell for that murder. Even though there are still eighteen chapters unpublished and perhaps unwritten, Lee's final scene compresses together all three major incidents in chapters 47-49, positing that George is Tulkinghorn's killer in a justified shooting and attempting to incorporate Jo's death at the same time.

It is clear that the Victorians found Jo's death in the novel both troubling and sublime, and the pre-emptive adaptations pick up on that. Dickens wrote Jo's death for maximum emotional impact in an intimate scene of sanctification where Woodcourt ushers Jo's soul into heaven as he repeats lines from the Lord's Prayer. At the moment of Jo's death, Dickens intones, "The light is come upon the dark benighted way. Dead!" (Dickens [1853] 1996: 677). The final paragraph in the chapter repeats the word "dead" as a drumbeat of tragedy that indicts upper class indifference to Jo's obscure sufferings:

Dead, your Majesty. Dead, my lords and gentlemen. Dead, Right Reverends and Wrong Reverends of every order. Dead, men and women, born with Heavenly compassion in your hearts. And dying thus around us, every day.

Dickens's resounding rhetoric around Jo's death critiques class issues East-End audiences might easily agree with, and the language itself strongly signals a dramatic climax for the novel even though it is only three-quarters complete. When Jo dies at the end of Lee's more helterskelter version, Lee makes Jo's death the ending to a narrative already resolved in the play 
and singles out the unruly thread that comes loose from the story's fabric. The final scene, ${ }^{6}$ which again illustrates the truncated and hurried nature of the adaptation, trundles Jo centre stage amid the happiness of couples united in marriage. Jarndyce, who himself appears onstage for the very first time in this last scene, suddenly asks, "Where is Joe?". There follow only three more speeches before Jo's rapid dispatch:

WOODCOURT: Alas, nothing can arrest [Jo's] disease. He is dying - his only hope and wish to see the child of him who was, as he states it, his best and only friend.

(Jo brought on ill)

ESTHER: Jo, you must rouse and recover. Friends are by, and many happy days are yet in store. JO: No, miss, not for I. For you there be. I can see thy father's face in thee and that voice. Yes - you be the very spit of him - but don't come too near me. I've got fever and I wouldn't harm thee for the world. Lay poor Jo in the pauper churchyard next to him, and put on my tombstone that he - he was werry good to me he was.

(Dies)

Tableau

The End

This scene acknowledges but fails to capitalise on the pathos as Dickens draws it out. So Lee acknowledges Jo's death but does not take time to revel in the tragic spectacle. On the other hand, Jo's death clearly cannot be ignored. Lee apparently sees this ending as essential, and he includes it in a significant though perfunctory way.

Lee's adaptation lifts a thread from the Bleak House tapestry that subsequent adaptors will single out and elaborate as the most important strand. Almost every Bleak House adaptation throughout the Victorian period ends with the death of Jo, except for those few that end with the death of Lady Dedlock. But Lady Dedlock was still alive in June of 1853 so that pre-emptive playwrights did not imagine her dire fate just as they did not imagine Hortense is Tulkinghorn's murderer. Lee's rival Pitt, the other 1853 stage pirate, does not kill off Lady Dedlock either. In fact, Pitt revives Nemo and restores him to Lady Dedlock, killing off Sir Leicester instead. Like Lee, Pitt also stages a restorative ending featuring a repristinated Lady Dedlock. ${ }^{7}$ But neither Pitt nor Lee actually stopped with virtue reaffirmed and justice triumphant because the narrative, in their view, ends with Jo. Though both the story and society at large are troubled by Bleak House's images of greedy lawyers (Tulkinghorn), grasping moneylenders (Smallweed), and treacherous though vague French conspiracies (Hortense), Lee portrays these as soundly defeated by virtuous English citizens. But both Pitt and Lee are unable to ignore Jo's plight. These early adaptors recognised immediately, though perhaps unconsciously, that Dickens's story is both about him and not about him.

\footnotetext{
${ }^{6}$ The final scene of all Bleak House adaptations that end with the death of Jo up through 1876 were controversial for another reason. The Lord Chamberlain's office, where all plays were submitted for licensing, forbade the use of the Lord's Prayer and required that playwrights omit this language. John Russell Stephens notes that this level of religious censorship for all plays "extended to the deletion of all passages and phrases quoted directly from the Scriptures or even implying any such association" (2010: 100). Bolton notes that the censorship had to do with a longstanding prohibition against mixing the sacred and the secular (1983: 84), a holdover as well from the eighteenth and early nineteenth centuries when theatres attracted rowdier and more disorderly crowds (Moody 2000: 14-17).

${ }^{7}$ George Dibdin Pitt's competing adaptation at the Pavilion Theatre, Bleak House, or The Spectre of the Ghost Walk (1853), ends this way: Since Sir Leicester is dead, Hawdon, who has been nursed back to health, rushes onstage and says, "I am the real Captain Hawdon - here, ready to defend my wife and daughter" (II. v). Phil Squod shoots Tulkinghorn, and then Hawdon attends to Jo as he expires - curtain.
} 
Lee must also have known that the novel's complete publication would likely render his adaptation obsolete, even if it was not obvious at the time that getting the ending wrong would have mattered to audiences. In any case Lee's play was short-lived and soon forgotten, only running for about three weeks (Dramatic Register 1853: 94). During that period, however, the play appears to have attracted initial audiences even though it was widely ignored by the press. One brief notice from The Theatrical Journal, quoted here in full, records the play's impact thus:

The great success of Bleak House, (although we cannot approve of the system of dramatizing unfinished works) - in conjunction with the talented company, caused this theatre to be crowded during the last week. The acting of Mr. W. Searle [who played Jo] merits highly favourable notice: his pathetic lamentation for his lost friend, in the scene of the burial ground, together with his ejaculation of 'he was very kind to me - he was,' is a truly artistic performance.

("Metropolitan" 1853: 182)

Though the tone is positive, this notice exhibits awareness of the play's unauthorised nature in two ways: one is the pirated form of the play, and the other is the poignancy of the unauthorised Jo himself. In this notice, which mentions no other Bleak House element, Jo is highlighted to the exclusion of any other plotline. Following Lee's lead, the notice brings Jo centre stage at the last moment in an exclusive spotlight of his own. So though Lee's adaptation did not achieve the great success of the later 1876 version, it does anticipate the narrative feature that will haunt almost all stage versions: the narrative coup de grace that Jo's death represents as both part of the plot and its own plot at the same time. It is Jo's death that unweaves the Bleak House narrative and, with that thread, stage pirates reweave the plot. Jo stole the show on stage so that even a seemingly critical character such as Esther was no match for him; the story could go on without Esther, as some later adaptors showed, but both early and later stage pirates recognised that it could not go on without Jo. As an unauthorised outsider to society, Jo threatened to exert new authority over the narrative even at this early stage in Bleak House's stage history.

\section{Bleak House Onstage (1876): J. P. Burnett, Bleak House, or Poor Jo}

Once Bleak House as a full narrative was published, subsequent stage pirates represented it as dominated by either Jo or Lady Dedlock - but mostly by Jo. In a few versions, Lady Dedlock laid claim to pirated narratives because the fallen woman was a staple of popular melodrama throughout the century. However, though she challenged Jo's popularity, she did not trump him. Adaptations from the 1870 s, the most prolific era for Bleak House on the Victorian stage, show how this struggle played out.

Dickens's death in 1870 prompted a new round of piracies. For the few Bleak House adaptations that centralised Lady Dedlock, the trendsetter was an American version by Henry Rendle that gradually gained momentum touring nationwide. Rendle's Chesney Wold, also advertised as Lady Dedlock and Hortense or sometimes merely as Bleak House, premiered in St. Louis, MO, on 19 October 1871 ("Theatrical" 1871:239). On a tour stop in San Francisco, 
a young British actress named Jennie Lee (no relation to Austin Lee above) was hired for the part of Jo, whom Rendle reimagined as a breeches role in line with melodramatic convention. ${ }^{8}$ Jennie Lee's Jo was meant to be second fiddle to Lady Dedlock, played by Madame Fanny Janauschek. The play's gimmick was that Janauschek played the parts of Lady Dedlock as well as Hortense. However, Jennie Lee's embodiment of Jo was so successful and touching that audiences and reviewers were bowled over. At the suggestion of well-known actor and playwright Dion Boucicault, Lee turned her success playing Jo into an entire poor-Jo-thecrossing-sweeper industry. Reportedly, after seeing her San Francisco performance, Boucicault said,

Tell that man of yours [Lee's husband was actor and playwright J. P. Burnett] to take the book of Bleak House and write a play making Jo the part, and you'll never want a penny and you can play Jo until you're seventy, if you don't get too fat.

(Quoted in Morley 1953: 177)

And that is exactly what she did. Lee reportedly played Jo for the last time in 1925, when she was nearly 70 years old. J. P. Burnett's play, licensed with the title Bleak House but mostly advertised as $J_{o}$, or Bleak House and eventually just $J_{o}$, made its London premiere at the Globe Theatre on 21 February $1876 .{ }^{9}$ The Globe attracted more fashionable audiences and undoubtedly lent that power to the play's high-profile success alongside the great number of press notices and reviews it received. Its initial run was more than one hundred performances before it went on to other venues, returning to the Globe again that year for an encore run (Davis 2017: 237). Jennie Lee went on to play Jo in India, China, Tasmania, Australia, New Zealand, and America - not to mention the dozens of times she played the role all over England (Bolton 1983: 104). Her popularity beyond the West End of London prompted Errol Sherson, in his 1925 retrospect London's Lost Theatres, to sniff, "“Jo' must be included with those phenomenal emotional successes which appeal to the unsophisticated and are always 'running' somewhere in the provinces" (1925: 241). Reviews from these outposts are so similar as to be monotonous, and, as in all reviews of this play, Jennie Lee was singled out as the featured performer practically to the exclusion of anyone else in the play. Looking back on Lee's infamous role from the vantage point of 1894, one critic notes:

The character [of Jo] was a play in itself, and thus proved how deeply-seated was the genuine instinct in the gifted [actress]. Everything was complete; the spectator felt that nothing was lacking. The [play itself] was raw and transpontine - a number of scenes and characters rudely put together. The physical gifts of the actress corresponded as though they had been furnished to order--the slight, frail, wasted street arab $[\mathrm{sic}]$ was there before us. The tones of the voice - a quaint gamut, now husky, now impudent; the fashion in which the broom was used; the air of stolid bewilderment; the sudden laugh; the genuine note of pathos ...- all these touches were inimitable. The actress and her part were convertible - Joe [sic] was Lee, and Lee was Joe.

(Fitzgerald 1894: 175-6)

\footnotetext{
${ }^{8}$ Women were often cast in breeches roles as a convention of melodrama in Victorian theatre. Breeches roles have been variously seen as "a way of sexualizing the performers, [while others suggest] that it is closer to androgyny or even a form of erasure of the performer's original gender" (Davis 2017: 35). Carolyn Williams suggests that, in the casting of waifs, "Female-to-male cross-dressing was also deployed to embody masculine vulnerability or weakness" (2010: 205).

${ }^{9}$ Prior to his London premiere, Burnett had staged the play in Liverpool at The Prince of Wales Theatre on 8 November 1875.
} 
So as Lee solidified her identity performing Jo, she simultaneously solidified through Jo the identity of the novel itself for many late Victorian audiences. She exemplified the theatrical phenomenon that a performer might embody a character so effectively that her portrayal lends authority to new ways of understanding as well as extending the narrative. In this, Jo bears a relationship to Pickwick's Sam Weller who, as Jacky Bratton suggests, "was at least partially created in the minds of many people" by a successful stage piracy produced in 1837, in which the playwright and the actor playing Weller collaboratively produced "a crystallization of the knowing Londoner whom Dickens drew from the culture around him, and his acceptance back into common culture extended the author's impact to people outside the reading audience" (2017: 23). Bratton points out that this may be

the first instance of the fruitful feedback between Dickens's popularity on stage and in print, a process that has subsequently been condemned as vulgarization of the novelist's work, but might better be regarded as one of its deep wells of creativity.

(2017: 22)

Jennie Lee and Burnett also, then, participated successfully in the creative collaboration Victorian piracy permits when a text is unmoored from its originator.

As a stage pirate in 1876, J. P Burnett partially reinstituted Austin Lee's reading from 1853 only more thoroughly and influentially. It is uncertain whether Burnett knew anything about the 1853 adaptations. He was born in 1846 and would have been only seven years old when Austin Lee's version was produced. Since neither of the 1853 versions were published, it is unlikely that he saw the manuscripts unless he sought them out independently from the Lord Chamberlain's office. Rendle's 1871 American version emphasising the role of Lady Dedlock would, of course, have been familiar to him since his wife played the part of Jo, and there were only one or two other Bleak House adaptations in the interim between 1853 and 1876 besides Rendle's: one in 1854 that experimented with staging both Jo's and Lady Dedlock's deaths in the final two scenes (and in that order), ${ }^{10}$ and one in 1874 that ends with Lady Dedlock's death while Jo lives on. ${ }^{11}$

Burnett's adaptation had a strong impact on Bleak House reception and interpretation as he deliberately and relentlessly centralised Jo in the narrative, re-appropriating him to inscribe Bleak House as Jo's story. In contrast to Austin Lee's 1853 version that revolves around romantic pairs, Burnett decentralises Esther's romance in favour of Jo's. Esther does appear as a character, but Allan Woodcourt is not mentioned at all. Act I begins with Jo at the Inkwich and ends with Jo ushering Lady Dedlock to Nemo's wretched burial site. The tableau that punctuates Act I's end is Jo alone in a spotlight mourning over Nemo's grave. Act II begins with Jo being interviewed about taking Lady Dedlock to Nemo's grave, and the final act ends with Jo's death. Jo appears in or is the focus of seven out of the eleven scenes in this three-act play. Much of the original Dedlock storyline is employed but is used to weave Jo's scenes together. In many ways, Burnett stuck closely to selected Dickens's scenes, both paraphrasing and plagiarising from the original. However, one of the biggest departures from Dickens's comes at the end. Just before Jo's big death scene, he has a tender moment with a love interest - Guster, the Snagsby's maid. They kiss - and not for the first time as we are told. Then Jo tells her, "Well, you's the only one as ever cared for me in this blessed world, ceptin him as is dead; he wos wery good to me, he wos" (III. ii). Though he is ragged and homeless, Jo is no longer a filthy, diseased untouchable. This invention for the stage repositions Jo as romantically viable,

\footnotetext{
${ }^{10}$ See Edmund Falconer's Bleak House (1854).

${ }^{11}$ See John Palgrave Simpson's Lady Dedlock's Secret (1874).
} 
displacing Esther as the romantic lead, and heightens the pathos of his death, a scene set outdoors in Tom-All-Alones. Instead of being gently reconciled to death by Allen Woodcourt at George's shooting gallery as in Dickens, Jo's death is witnessed by a crowd of anonymous lower-class onlookers and friends, including Bucket who holds him as he dies:

JO: ... It's turned wery dark. Is there any light a'comin'?

BUCKET: (Softly) It is coming fast, Jo. - Jo, my poor fellow.

JO: I hear you, sir, in the dark, but I'm a gropin' - a gropin' - let me catch hold of your hand.

BUCKET: (Very softly) Jo, can you say what I say?

JO: (Very feebly) Anythink as you say, sir.

BUCKET: (Uncovering, all do the same) "Our Father" -

JO: "Our Father" - yes, that's wery good, sir.

BUCKET: "Which art in heaven -"

JO: "Art in heaven" - Is the light a'comin', sir?

BUCKET: It's close at hand.

JO: (Moonlight has fallen on his face - he pauses - smiles - mutters gladly) I'm movin' on.

(Falls back dead in Bucket's arms. Music swells out forte.)

(Slow drop.)

Finis.

(III. iii.)

The scene is a combination of plagiarism and paraphrase. In Dickens, Jo dies mid-sentence as he tries to repeat Woodcourt's words so that his last utterance is "Hallowed be - thy -" (Dickens [1853] 1996: 677). Instead of this, Burnett employs another of Dickens's metaphors from the novel - "I'm movin' on" - as the play's final speech, and since this metaphor is strongly connected with Bucket, it seems appropriate here. It is worth noting that Burnett himself often played the role of Bucket, so audiences were left with the final, touching tableau in which Burnett held his wife Jennie Lee in his arms. Romance and pathos were joined in life and onstage at the same moment.

Burnett's successful adaptation laid claim to the narrative in a more thorough and knowledgeable way than Lee's 1853 play, though it also cut out some seemingly intrinsic elements. Like many Victorian adaptations, Burnett's did not feature elements that seemed vital or spectacular about Bleak House to its first readers in 1853. For example, Esther never gets smallpox nor is she disfigured (no Victorian stage version, in fact, includes this feature from the novel), and Krook's controversial spontaneous combustion, an event that seems eminently suited to the popular theatre pyrotechnics of the time, is most often ignored. ${ }^{12}$ Burnett's version minimises Jo's main competitors, Lady Dedlock and Esther. Esther's narrator role in the novel does not privilege her as a romantic lead, and Lady Dedlock's demise, which takes place offstage in Burnett, lacks the power of Jo's. Her death is announced by an anonymous supernumerary police officer who tells Bucket merely that "Lady Dedlock has been found dead, sir" (III. i). Though Sir Leicester is shaken by this news, this event ends the Dedlock plot in the play, and the final two scenes are all Jo and Bucket, with Guster, Jenny (the bricklayer's wife), and Snagsby looking on.

\footnotetext{
${ }^{12}$ Krook's spontaneous combustion set off a controversy in the press when Dickens published that chapter of the novel. See Gordon S. Haight (1955) for more on this topic. Pitt's 1853 version mentions but does not stage Krook's spontaneous combustion, with Guppy saying, "He was lighting his pipe when the flame caught his breath, and he was burnt up to a cinder in a jiffy" (II. iv.). In George Lander's 1876 version, Guppy merely mentions, without further comment, that Krook has "died of internal combustion through the rum in his stummick catching fire" (I. iv.).
} 
The play's eventual displacement of Bleak House with Jo as a title signals that Burnett's re-appropriation is complete and completely successful. Jo has taken over the narrative in a new genre and obliterated the original title altogether. Burnett's play brings a role on the narrative's periphery to the centre by reimagining Jo as a breeches part, giving him a new life on the melodramatic stage where he not only draws huge audiences but is resurrected night after night for decades. Jo is no longer Dickens's "Toughey" dead too soon through both social and narrative neglect; melodramatic convention empowers Jo, bringing a minor part from the novel into the spotlight on stage. Touched off by Jennie Lee's phenomenal performance, 1876 became the year of Jo with at least ten versions of Bleak House hitting the boards. All of the 1876 adaptations use Jo's name in either the main or subtitle. In response to this "avalanche of dramas," Malcolm Morley remarks, "Never at one time were so many plays based on the same Dickens's [sic] story being performed... The law of copyright was powerless to prevent them doing so" (1953: 178). So in their turn, pirated adaptations themselves were apt to be pirated in the frenzy to fill theatre seats with paying customers.

Burnett's piracy was truly a turning point in Bleak House reception, though some critics documented Jo's triumph with surprise and resistance. Frederick Wedmore in particular was taken aback by Jo's predominance in the sea of Bleak House characters, indignantly claiming that the novel is clearly about "the Dedlock Group" and that Jo is merely a bit player in their larger tragedy (1876: 223). But Wedmore is in the minority given the way global audiences were drawn to Burnett's dramatisation. Eventually, Jo imploded under the weight of his own mythology as well as changing tastes in the late Victorian period. George Bernard Shaw wrote a murderous review of the play in 1896 that signalled the demise of the Victorian sensibilities that created it. He notes that mid-Victorian sentimentality is rather comic on the late Victorian stage. But it is a commonplace of all reviews - even those of such highbrows as Shaw himself - to admit Jo's power, however reluctantly and however qualified their praise. Shaw, who saw the play in May 1896, remarks:

All that can be said for Miss Jennie Lee's Jo nowadays is that if the part had been left between herself and Dickens, something credible and genuinely moving might have come of it. But Mr. Burnett has carefully laid out his lines and stage business for the crudest and falsest stage pathos and stage facetiousness. Jo is one moment a cheeky street arab [sic], and, the next, is directly expressing, to slow music, not the darkened ideas of Jo, but Mr. Burnett's version of the compassionate horror roused in the social and political consciousness of Dickens by the case of Jo and his fellow-outcasts. Dickens himself is not wholly guiltless of this: in the novel one or two speeches are at bottom conscious social criticisms; but it is not the business of the dramatist to develop a couple of undramatic slips in a novel into a main feature of the leading part in a play.

(1932: 135)

Though he calls the late Victorian production of this play an "astonishing" spectacle of "grotesque" melodramatics, he has the grace to wonder, "What will the stage sentimentalities on which I drop a tear of sensibility today seem like a quarter of a century hence[?]" (1932: 133). Shaw highlights the tensions between authorised Dickens and unauthorised Burnett, suggesting that the play should never have been written. In his view, the play makes off with the narrative and asserts a new though spurious authority that cannot be sustained.

Bolton remarks on the way that Bleak House pirates "seemed to require several decades to solve the problems of dramatic adaptation and generate highly successful plays from the ur-stuff of the novel" (1987: 349). Nonetheless, Jo owned the Bleak House narrative starting in the 1870s when he became "the emotional center" (Bolton 1983: 90) of the plot until the productions that established his ascendancy lost their emotional impact and faded from 
memory. Though the novel had long been in print by the 1870 s, successful adaptation was belated while playwrights sorted through the novel's multivocality for the tone that would resonate most strongly on the late Victorian stage. They found it, for a time, in Jo's plaintive voice and tragic death.

\section{Conclusion}

But what did Victorian audiences make of adaptations without Dickens's endorsement and that indeed took liberties with the original text? Bolton asserts that liberal adaptation for the stage was absolutely necessary since Bleak House is a "very unplaylike ... novel in sheer bulk and multiplicity of interests" (1983: 81). However, notions of what constitutes a good or successful adaptation today may differ from Victorian expectations. Discerning popular audience reception of stage piracies requires what Chris Louttit calls a "critically imaginative reconstruction" (2019: 193), especially for those adaptations produced in London's East End. These were often ignored by Victorian reviewers, so even that measure of audience reception is scarce (193). Perhaps partially due to the breadth of readers' familiarity with Dickens, Victorian audiences may not have expected comprehensiveness and may have been open to transferring authority from print to performance in the case of successful adaptations. This textual familiarity, as Louttit points out, may have led them to look for Dickens's signature character lines and catchphrases (201), which Jo has in abundance given his Cockney slang and syntax. In the two Bleak House adaptations examined here, for instance, the playwrights are careful to incorporate "he was wos wery good to me, he wos" at significant points in Jo's performance but especially in the deathbed scene where Austin Lee leaves it on Jo's lips in the final moment and J. P. Burnett diffuses it more generally. A Victorian audience's expectations, then, might best be understood as a give-and-take between reading and theatre. Deborah Vlock's study of the relationship between these two concludes with the image of a Victorian reader who, far from reading privately in solitude, might better be thought of as "sitting in a theatre, the imagination's playhouse, with a book in one hand and an eye and ear on the stage" (1998: 192). Thus audiences for the first Bleak House adaptations, some still anticipating the novel's conclusion, were holding only the serial parts in their metaphorical hands. They watched while still in suspense and withheld, perhaps, a too-critical judgement of an adaptation's achievement since they were imagining an outcome alongside the pirates. Early Bleak House piracies, then, might be usefully seen as making provisional forays into the narrative, testing and trying out selections and combinations that nonetheless identify the narrative's achievement in that moment. When a pirated Bleak House later became a hit decades after the first staging attempts, it played to a new generation whose relationship to the novel had changed. These audiences, to whom Bleak House was long known, may have harboured a reader's nostalgia for a beloved narrative that may have grown vague or less detailed in their memories. Liberties taken with an adaptation may have seemed less egregious, and, like the earlier audiences, they may also have responded to Burnett's play with enthusiasm for the voices, particularly the voice of Jo, that stood out most vividly in their memories.

The first reviews of the novel provide support for the power of Jo's voice from the novel's outset. Though many of the novel's initial reviews conscientiously distributed attention among a full range of Dickens's Bleak House characters, a good number also identified (or attempted to identify) a central character thread that unified the novel as a whole. Some reviews intimate or state outright that the Lady Dedlock plot was the novel's powerful central draw; ${ }^{13}$

\footnotetext{
${ }^{13}$ See The Critic (Review 1853a), New Quarterly Review (Review 1853b), The Examiner (Review 1853c) and Bentley's Miscellany (Review 1853d).
} 
others, such as The Spectator, identified the relationship of Lady Dedlock and Esther Summerson as key, though one reviewer remarks that "the whole Dedlock set ... might be eliminated from the book without damage to the great Chancery suit, or perceptible effect on the remaining characters" (Brimley 1853: 923). However, other initial reviewers seem to intuit the way that Jo will eventually emerge from Bleak House's tumultuous throng. For example, The Athenaeum singles out Jo in this way:

Perhaps among all the waifs and strays, the beggars and the outcasts, in behalf of whose humanity our author has again and again appealed to a world too apt to forget their existence, he has never produced anything more rueful, more pitiable, more complete than Jo ... The book would live on the strength alone of [Jo's deathbed scene].

(Review 1853e: 1087)

\section{The Westminster Review concurs:}

There are chapters in ... [Bleak House] that may be taken as the maturest and best things ever written by their author. All that relates to that type of a class, the poor street outcast, 'Jo,' is told with the most exquisite skill and feeling, and will be remembered always as one of the choice things that do honour to our literature.

(“Contemporary" 1853: 309)

And The Eclectic Review, which had been very critical of the novel, identifies Jo as "the gem of 'Bleak House"' (Review 1853f: 672). Even early on in the novel's career, then, Jo's plotline emerged as a Bleak House wild card with its own narrative viability. Thus Jo was part of the critical discourse around the novel as it was being published, but the reviews show that some readers already found the novel's multivocality unsettling and Dickens equivocal in providing a clear focus.

Dickens, with his canonical status, survived these early critiques of the novel as well as the stage pirates' onslaughts. Bleak House as a novel moved past the Victorian period with Dickens's multivocality intact alongside the narrative possibilities stage pirates established. As they appropriated and re-appropriated the narrative, they did what all readers do according to John Glavin, who makes the case that to merely read Dickens is to update the text and, in Bourdieu's words, to "redeploy a certain kind of literary capital" (Quoted in Glavin 1999: 2). Glavin argues that all reading and interpretation are belated ways of adapting a text: Dickens's "pages may be there in front of us, but the text waits on our recovery" (1999: 2). Even Victorian Bleak House pirates, then, are part of a community of readers whose illicit adaptations exploited "the 'literary capital' already accumulated in Dickens's books" (2). Alongside the literary pirates/adaptors themselves, readers and audiences played a role in lending authority to unauthorised Bleak House adaptations as new iterations of its literary capital were built up and dispersed. Thus both the successful and the unsuccessful pirates offer discrete readings worth our consideration. They obscure parts of Bleak House while materialising alternative readings, reshaping the narrative in favour of the illicit and sometimes unresolved/unresolvable storyline. They assert and disseminate a Bleak House narrative of their own that reweaves certain story threads but that also makes legible for a time different textual nuances and patterns. Bleak House piracies with Jo at the centre had a shelf life of about 40 years, but it is clear that Jo the crossing-sweeper was a phenomenon when Dickens wrote him and that he carried the narrative itself into the twentieth century. 


\section{Bibliography}

Alexander, Isabella. 2010a. Copyright Law and the Public Interest in the Nineteenth Century. Portland: Hart.

Alexander, Isabella. 2010b. "Neither Bolt nor Chain, Iron Safe nor Private Watchman, Can Prevent the Theft of Words': The Birth of the Performing Right in Britain." In Privilege and Property: Essays on the History of Copyright, edited by Ronan Deazley, Martin Kretschmer and Lionel Bently, 321-46. Cambridge: Open Book.

Altick, Richard. 1998. The English Common Reader, 2nd ed. Columbus: Ohio State University Press.

Bolton, H. Philip. 1983. "Bleak House and the Playhouse.” Dickens Studies Annual, 12: 81-116.

Bolton, H. Philip. 1987. Dickens Dramatized. Boston: G. K. Hall.

Bratton, Jacky. 2017. "Introduction." In Dickensian Dramas: Plays from Charles Dickens, edited by Jacky Bratton, 13-34. Vol. 1. Oxford: Oxford University Press.

Brimley, George. 1853. "Dickens's Bleak House.” The Spectator, 26.1317 (24 September): 923-5.

Burnett, J. P. 1876. Bleak House. Lord Chamberlain's Collection, British Library. Add. Ms. 53162 B.

Cohen, Monica. 2018. Pirating Fictions: Ownership and Creativity in Nineteenth-Century Popular Culture. Charlottesville: University of Virginia Press.

“Contemporary Literature of England." 1853. The Westminster Review (October): 297-310.

Davey, Peter. 1912. Poor Jo, A New Version of an Old Play. Pettingill Collection, Templeman Library, University of Kent. MSS.P.65.

Davis, Jim. 2017. “Introduction.” In Dickensian Dramas: Plays from Charles Dickens, edited by Jim Davis, 13-40. Vol. 2. Oxford: Oxford University Press.

Davis, Jim, and Victor Emeljanow. 2001. Reflecting the Audience: London Theatregoing, 1840-1880. Iowa City: University of Iowa Press.

Dickens, Charles. [1853] 1996. Bleak House, edited by Stephen Gill. Oxford: Oxford University Press.

The Dramatic Register for 1853. 1853. London: Thomas Hailes Lacy.

Falconer, Edmund. 1854. Bleak House, A Dramatic Sketch from Mr. Charles Dickens's Work in Two Acts. Lord Chamberlain's Collection, British Library. Add Ms 52947 R.

Fielding, K. J. 1956. "Charles Reade and Dickens - A Fight against Piracy." Theatre Notebook, 10: 106-11.

Fitzgerald, Percy. 1894. "On Some of the Old Actors.” The Gentleman's Magazine, 276 (February): 170-81.

Fulkerson, Richard. 1974. "Oliver Twist in the Victorian Theatre.” The Dickensian, 70: 83-95.

Glavin, John. 1999. After Dickens: Reading, Adaptation \& Performance. Cambridge: Cambridge University Press. DOI: https://doi.org/10.1017/CBO9780511484810

Haight, Gordon S. 1955. "Dickens and Lewes on Spontaneous Combustion." Nineteenth-Century Fiction, 10.1: 53-63.

Hutcheon, Linda. 2012. A Theory of Adaptation, 2nd ed. New York: Routledge.

Johnstone, J. B. 1876. Jo, A Drama in Four Acts. Pettingill Collection, Templeman Library, University of Kent. MSS.J.34.

Lander, George. 1876. Bleak House, or Poor Jo. London: J. Dicks, 1883.

Lee, Austin. 1853. Bleak House, in Two Acts. Lord Chamberlain's Collection, British Library. Add. Ms. 52940 K.

Louttit, Chris. 2019. "Popular Dickens: Changing Bleak House for the East End Stage." In Charles Dickens as an Agent of Change, edited by Joachim Frenk and Lena Staveker, 191-204. Ithaca: Cornell University Press. 
Mattacks, Kate. 2016. "Acts of Piracy: Black Ey'd Susan, Theatrical Publishing and the Victorian Stage." In Pirates and Mutineers of the Nineteenth Century: Swashbucklers and Swindlers, edited by Grace Moore, 133-47. New York: Routledge.

Miller, Derek. 2018. Copyright and the Value of Performance, 1770-1911. Cambridge: Cambridge University Press. DOI: https://doi.org/10.1017/9781108349284

“Metropolitan Theatres." 1853. The Theatrical Journal, 16 (June): 182-3.

Moody, Jane. 2000. Illegitimate Theatre in London, 1770-1840. Cambridge: Cambridge University Press.

Morley, Malcolm. 1953. "Bleak House Scene.” The Dickensian, 49: 175-82.

Patten, Robert L. 2018. Charles Dickens and His Publishers, 2nd ed. Oxford: Oxford University Press.

Pitt, George Dibdin. 1853. Bleak House, or The Spectre of the Ghost Walk. Lord Chamberlain's Collection, British Library. Add. Ms. 52940 M.

Review of Bleak House, by Charles Dickens. 1853a. "Fiction." The Critic (15 September): 490-1.

Review of Bleak House, by Charles Dickens. 1853b. "Retrospect of the Literature of the Quarter." New Quarterly Review (October): 431-40.

Review of Bleak House, by Charles Dickens. 1853c. The Examiner (8 October): 643-5.

Review of Bleak House, by Charles Dickens. 1853d. "A Gossip about New Books.” Bentley's Miscellany (July): 367-74.

Review of Bleak House, by Charles Dickens. 1853e. The Athenaeum (17 September): 1087-88.

Review of Bleak House, by Charles Dickens. 1853f. The Eclectic Review (December): 665-79.

Seville, Catherine. 2007. "Edward Bulwer Lytton Dreams of Copyright: 'It might make me a rich man.'” In Victorian Literature and Finance, edited by Francis O'Gorman, 55-72. Oxford: Oxford University Press.

Shaw, George Bernard. 1932. Our Theatre in the Nineties. Vol. 2. London: Constable.

Sherson, Errol. 1925. London's Lost Theatres of the Nineteenth Century. London: John Lane.

Simpson, John Palgrave. 1874. Lady Dedlock's Secret. Lord Chamberlain's Collection, British Library. Add. Ms. 53136 A.

Smith, Julianne. 2014. "Bleak House on London's East End Stage, 1853: George Dibdin Pitt and Dickens at the Royal Pavilion Theatre." Nineteenth-Century Theatre \& Film, 42.1: 2-20. DOI: https://doi.org/10.7227/NCTF.0008

Stephens, John Russell. 2021. The Censorship of English Drama 1824-1901. Cambridge: Cambridge University Press.

"The Theatres." 1881. The Times (12 March): 10C.

“Theatrical Record." 1871. The New York Clipper (28 October): 238-9. Center for Research Libraries Global Resources Network, https://dds-crl-edu.lib.pepperdine.edu/crldelivery/16638. Accessed 17 Feb. 2018.

Vlock, Deborah. 1998. Dickens, Novel Reading, and the Victorian Popular Theatre. Cambridge: Cambridge University Press.

Wedmore, Frederick. 1876. "The Stage.” The Academy, 225 (August 26): 223.

Williams, Carolyn. 2010. Gilbert and Sullivan: Gender Genre Parody. New York: Columbia University Press. DOI: https://doi.org/10.7312/will14804

Williams, Michael. 1883. Some London Theatres, Past and Present. London: Sampson Low, Marston, Searle \& Rivington. 